\title{
Factors Affecting Bone Mineral Density in Male Patients with Primary Progressive Multiple Sclerosis
}

\author{
Primer Progresif Multipl Sklerozlu Erkek Hastalarda Kemik Mineral Yoğunluğunu \\ Etkileyen Faktörler
}

\author{
(D) Ası Çalışkan Arıcan, (D) Yeşim Gökçe Kutsal, (D) Nazire Pınar Acar*, (D) Filiz Akbıyık**, (D) Sevilay Karahan***, \\ (D) Rana Karabudak* \\ Hacettepe University Faculty of Medicine, Department of Physical Medicine and Rehabilitation, Ankara, Turkey \\ * Hacettepe University Faculty of Medicine, Department of Neurology, Ankara, Turkey \\ **Hacettepe University Faculty of Medicine, Department of Biochemistry Ankara, Turkey \\ ***Hacettepe University Faculty of Medicine, Department of Biostatistics, Ankara, Turkey
}

\section{Abstract}

Objective: Osteoporosis (OP) is one of the most frequent metabolic bone disorders worldwide, male OP is still underestimated and undertreated. Primary progressive multiple sclerosis (PPMS) is considered as an important cause of secondary OP in males and there is limited data on this condition in Turkey. This study aimed to evaluate the bone mineral density (BMD) of male PPMS patients and the possible clinical and laboratory interacting factors as well as to also define the correlation between BMD and bone turnover markers (BTM).

Materials and Methods: In this study, 26 male PPMS patients and 20 age-matched healthy volunteers were evaluated by the Expanded Disability Status Scale (EDSS), femoral and lumbar BMD, biochemical and hormonal tests and BTMs.

Results: Demographic characteristics were statistically similar between the groups. Mean values for patient age, disease duration and EDSS score were $42.5 \pm 10.0$ years, $3.5 \pm 1.5$ years and $4.6 \pm 1.6$, respectively. Although we found a significant difference in BMD and carboxy-terminal telopeptide levels between PPMS patients and the control group, there were no significant correlations between sex hormone binding globülin levels, EDSS, BMD scores, BTMs and other biochemical variables.

Conclusion: BMD scores were lower in the patient group compared to the control group. This study highlights the importance of considering bone health in male PPMS patients and reminds that strategies should be developed as part of the management plan.

Keywords: Multiple sclerosis, bone mineral density, osteoporosis

\section{$\ddot{O z}$}

Amaç: Osteoporoz (OP) dünya çapında en sık görülen metabolik kemik bozukluklarından biri olmasına rağmen, erkek OP’si halen yeterince göz önüne alınmamakta ve tedavi edilmemektedir. Primer progresif multipl skleroz (PPMS), erkeklerde ikincil OP'nin önemli bir nedeni olarak kabul edilmekte olup, Türkiye'de konu ile ilgili veriler sınırıdır. Bu araştırmada erkek PPMS hastalarının kemik mineral yoğunluklarının (KMY) incelenmesi, etkileşen olası klinik ve laboratuvar faktörlerin saptanması ve ayrıca KMY ile biyokimyasal kemik döngü belirteçleri (BKDB) arasındaki korelasyonun tanımlanması amaçlanmıştır.

Gereç ve Yöntem: Yirmi altı erkek PPMS hastası ve 20 yaş uyumlu sağlıklı gönüllü Genişlemiş Özürlülük Durum Ölçeği (EDSS), femoral ve lomber KMY, biyokimyasal ve hormonal testler ve BKDB ile değerlendirildi.

Bulgular: Demografik özellikler gruplar arasında istatistiksel olarak benzerdi. Hastaların yaş, hastalık süresi ve EDSS skoru için ortalama değerler

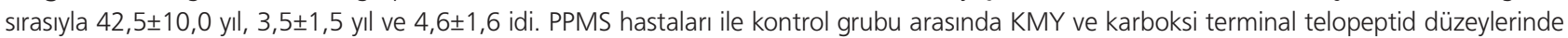
anlamlı bir fark bulunmuş olsa da cinsiyet hormonu bağlayıcı globulin düzeyleri, EDSS, KMY skorları, BKDB'ler ve diğer biyokimyasal değişkenler arasında anlamlı korelasyon saptanmadı.

Sonuç: KMY skorlarının hasta grubunda kontrol grubuna göre daha düşük olduğu belirlendi. Bu çalışma erkek PPMS hastalarında kemik sağlığının göz önünde bulundurmanın önemini vurgulamakta ve tedavi planının stratejik bir parçası olarak ele alınması gerektiğini hatırlatmaktadır.

Anahtar kelimeler: Multipl skleroz, kemik mineral yoğunluğu, osteoporoz

Address for Correspondence/Yazışma Adresi: Uzm. Dr. Aslı Çalışkan Arıcan, Hacettepe University Faculty of Medicine, Department of Physical Medicine and Rehabilitation, Ankara, Turkey

Phone: +90 5053187786 E-mail: asli.c.arican@hotmail.com ORCID ID: orcid.org/0000-0003-3606-2863

Received/Geliş Tarihi: 04.07.2020 Accepted/Kabul Tarihi: 14.07.2020

${ }^{\circ}$ Copyright 2020 by the Turkish Osteoporosis Society / Turkish Journal of Osteoporosis published by Galenos Publishing House 


\section{Introduction}

Osteoporosis (OP) is one of the most frequent metabolic bone disorders worldwide and male OP is still underestimated and undertreated, which has significant clinical and social consequences (1). About two-thirds of men have secondary OP and since diagnosis is important to define the prognosis and to choose the appropriate treatment, it is recommended to investigate young individuals and men under 65 years of age for other underlying causes of OP (1-3).

Multiple sclerosis (MS) is considered as an important cause of secondary OP (4). Since MS is predominantly seen in females, $\mathrm{OP}$ in male primary progressive MS (PPMS) patients are underrated. Drake et al. (5) identified multiple risk factors for osteoporotic fractures in men, but concluded that, usefulness for stratifying and selecting men for bone mineral density (BMD) testing remains uncertain. So not only the BMD but clinical and laboratory contributing factors should also be evaluated in males.

There is limited data about the effects of MS on male OP in Turkey.

This study aimed to evaluate BMD among male PPMS patients excluding factors such as chronic immobilization and oral glucocorticoid use, which can be two importing confounding factors. Bone tunover markers (BTM) commonly used as bone formation marker include serum osteocalcin (OC), and serum Carboxyterminal telopeptide of collagen I (CTX) as bone resorption marker for the evaluation of bone turnover (6). We also aimed to define the correlation between BMD and BTM for use in clinical practice to give information about bone metabolism earlier in a cheaper, reproducible way that does not have any radiation risk.

\section{Materials and Methods}

\section{Ethics Statement}

This study was approved by the Hacettepe University Noninterventional Clinical Research Ethics Committee (decision no: GO 14/524-06) and carried out in accordance with the Declaration of Helsinki. Written informed consent was obtained from all participants.

\section{Study Design and Participants}

Twenty six male patients who had been diagnosed as PPMS according to the 2010 McDonald Diagnosis Criteria, for at least 1 year prior to the study and aged between 24-60 years were enrolled (7).

Age and gender matched 20 controls were also enrolled in this study. Healthy volunteers with normal cognitive function, aged between 32-60 years old, and having a BMI between 20 and 40 were included. Control participants did not have any diseases or medication use which affected bone metabolism.

The evaluation of the patients and the control groups were performed in Hacettepe University Faculty of Medicine, Department of Physical Medicine and Rehabilitation clinic.
All the participants' demographics, such as age, height, weight, body mass index (BMI), gender, occupation, and education status were recorded in the participant evaluation form. Smoking and alcohol consumption habits, concomitant systemic diseases, and medications were also recorded. Family history of MS, OP, or pathological/fargility fractures were questioned.

MS type, duration, and patient age at diagnosis were recorded on the participant evaluation form. For standardization, The Expanded Disability Status scale (EDSS) was performed by the same neurologist (8).

\section{Laboratory Tests}

Blood was collected from participants after a minimum of eight hours fasting and tested for complete blood count and erythrocyte sedimentation rate. Plasma levels of calcium, sodium, magnesium, phosphate, blood sugar, alanine transaminase, aspartate transaminase, alkaline phosphatase, gamma glutamyl transferase, blood urea nitrogen, thyroid stimulating hormone, parathyroid hormone, 25-hydroxy vitamin D3, sex hormone binding globulin (SHBG), testosterone, growth hormone, OC and CTX were evaluated in Hacettepe University Hospital Department of Biochemistry.

CTX levels were measured with the Human Cross Linked C-telopeptide of Type I Collagen ELISA Kit (Elabscience, Houston, TX, USA). Reference values selected were concordant with the Turkish population.

\section{Bone Mineral Density Evaluation}

BMD was evaluated by dual-energy X-ray densitometry at Hacettepe University Hospital, Clinic of Radiology with the Lunar Prodigy Advance Bone Densitometer (GE, Chicago, IL, USA). Diagnosis of OP, osteopenia, or normal BMD was accessed with T-score values. The T-scores of L1-L4 vertebra and the total femur bone is used for diagnosis. The mismatch of the measured values is evaluated as either a major or minor mismatch. According to the World Health Organization's criteria, a major mismatch is if one of the measured regions is between OP limits but the other one is in normal limits. A minor mismatch is if one region is osteopenic but the other is either normal or osteopenic (9). As recommended by the writing group for the ISCD Position Development Conference, not only the T-scores but Z-scores were also taken into consideration (10).

\section{Statistical Analysis}

The IBM SPSS (Statistical Package for Social Sciences for Windows) 22.0 program was used for statistical analysis. A type 1 error level of 0.05 and a power level of $80 \%$ determined the number of participants to enroll. It was predicted that there would be a difference of at least 0.8 units between the MS and control groups according to T-score means (standard deviation: 1.43). Differences in the numerical variables between MS and control groups were assessed by independent sample t-test or Mann-Whitney $U$ test. Relations between categorical variables were evaluated using the chi-square test. BMD, bone 
formation and resorption markers, and SHBG relationships were evaluated using the Pearson or Spearman correlation coefficient. A $p$ value $<0.05$ was considered statistically significant.

\section{Results}

The demographics and tobacco and alcohol consumption were statistically similar in both groups. Mean age of the patient group was $42.5 \pm 10.0$ (24-60) years, whereas mean disease duration was $3.5 \pm 1.5$ years.

A significant difference was found BMI between the patient and the control group $(p<0.01)$. Basic characteristics of the study population are shown in Table 1.

25-hydroxy vitamin D levels were found to be $18.5 \pm 9.5 \mathrm{ng} / \mathrm{mL}$ in the patient group and $19.5 \pm 6.3 \mathrm{ng} / \mathrm{mL}$ in the control group ( $p>0.05)$. Some other laboratory results of the study population are given in Table 2 .

Regarding the BMD measurements; femoral BMD ( $p=0.01)$, femoral T-scores $(p=0.04)$, and femoral Z-scores $(p=0.05)$ were lower in the patient group. The comparison of BMD, Vitamin D, CTX, and OC levels between PPMS patients and the control group is shown in Figure 1.

Although we found a significant difference in BMD and CTX levels between PPMS patients and control group, there were no significant correlations between SHBG levels, EDSS, BMD scores, biomarkers (CTX and $\mathrm{OC}$ ), and other biochemical variables. However, the $p$ values were close to the significant value. BMD scores were lower in the patient group compared to the control

\section{Table 1. Characteristics of the study population}

\begin{tabular}{|c|c|c|c|}
\hline & MS n=26 & $\begin{array}{l}\text { Control } \\
\text { group } \\
n=20\end{array}$ & $\mathbf{p}$ \\
\hline Mean age (years) & $42.5 \pm 10.0$ & $42.7 \pm 7.9$ & 0.942 \\
\hline BMI $\left(\mathrm{kg} / \mathrm{m}^{2}\right)$ & $24.05 \pm 2.98$ & $26.47 \pm 2.83$ & 0.008 \\
\hline \multicolumn{4}{|l|}{ Educational status } \\
\hline Illiterate & 0 & $1(5 \%)$ & \multirow{5}{*}{0.170} \\
\hline Literate & $1(5 \%)$ & 0 & \\
\hline Primary education & $7(27 \%)$ & $2(10 \%)$ & \\
\hline High school & $8(31 \%)$ & $11(55 \%)$ & \\
\hline University & $10(39 \%)$ & $6(30 \%)$ & \\
\hline \multicolumn{4}{|l|}{ Marital status } \\
\hline Married & $18(69 \%)$ & $20(100 \%)$ & \multirow{3}{*}{0.005} \\
\hline Single & $7(27 \%)$ & - & \\
\hline Divorced & $1(4 \%)$ & - & \\
\hline \multicolumn{4}{|l|}{ Occupation } \\
\hline Government official & $10(39 \%)$ & $13(65 \%)$ & \multirow{4}{*}{0.022} \\
\hline Retired & $1(4 \%)$ & $3(15 \%)$ & \\
\hline Unemployed & $4(15 \%)$ & - & \\
\hline Self-employed & $11(42 \%)$ & $4(20 \%)$ & \\
\hline
\end{tabular}

group. Comparison of the CTX and OC levels of the PPMS patients and control group is given in Figure 2 and comparison of the BMD results between PPMS patients and control group is given in Figure 3.

The mean EDSS score was found as: $4.6 \pm 1.6$ and the distribution of EDSS Scores of PPMS Patients is given in Figure 4.

\section{Discussion}

Bone is a dynamic tissue that is continuously regenerated and destroyed. MS is a chronic autoimmune disease of the central nervous system that results in varying degrees of disability. Patients with MS have multiple risk factors for osteoporotic fractures, such as progressive immobilization, long-term glucocorticoids treatment or vitamin D deficiency (11).

There may also be several other confounding factors that effect the bone metabolism in MS patients. In our study, demographics and tobacco and alcohol consumption were statistically similar in both groups. There was a significant difference of BMI between the patient and the control group. This may be important due to the relationship between low $\mathrm{BMI}$, low BMD levels, and the possible risk of osteoporotic fractures in the future. Hence some studies found that increased BMI is associated with elevated BMD levels and a reduced risk of fractures due to OP (12).

Femoral BMD, femoral T-scores, and femoral Z-scores were lower in the patient group compared with the controls. SHBG levels and lumbar BMD scores were negatively correlated in the patient group. This may be an important confounding factor. But there was no significant correlation between SHBG levels, EDSS scores, BMD, biomarkers, and other biochemical variables. However, $p$ values were close to the significant value.

In young adults, MS is a leading cause of disability and triggers

Table 2. Some laboratory results of the study population

\begin{tabular}{|l|l|l|l|}
\hline & $\begin{array}{l}\text { PPMS } \\
\mathbf{n = 2 6}\end{array}$ & $\begin{array}{l}\text { Control } \\
\mathbf{n = 2 0}\end{array}$ & $\mathbf{p}^{*}$ \\
\hline ALT & $25.6( \pm 12.8)$ & $25.2( \pm 11.5)$ & 0.7 \\
\hline GGT & $39.5( \pm 32.5)$ & $29.4( \pm 23.2)$ & 0.8 \\
\hline Creatinine & $1.3( \pm 2)$ & $0.8( \pm 0.1)$ & 0.7 \\
\hline GH & $0.15( \pm 0.3)$ & $0.09( \pm 0.08)$ & 0.5 \\
\hline SHBG & $35.5( \pm 19.7)$ & $30.4( \pm 18.1)$ & 0.1 \\
\hline TSH & $1.4( \pm 0.8)$ & $1.2( \pm 0.4)$ & 0.1 \\
\hline Testosteron & $309.2( \pm 73.4)$ & $330.8( \pm 109)$ & 0.4 \\
\hline PTH & $39.1( \pm 14.7)$ & $41.3( \pm 14.8)$ & 0.6 \\
\hline CTX & $0.261( \pm 0.23)$ & $0.398( \pm 1.75)$ & 0.1 \\
\hline Osteocalcin & $2.8( \pm 3.9)$ & $2.1( \pm 0.2)$ & 0.8 \\
\hline $\begin{array}{l}\text { *PPMS and Control group p<0.05 is significant, **Standart daviation, Mann- } \\
\text { Whitney U test, PPMS: Primary progressive multiple sclerosis, ALT: Alanine } \\
\text { transaminase, GGT: Gamma glutamyl transferase, GH: Growth hormone, } \\
\text { SHBG: Sex hormone binding globulin, TSH: Thyroid stimulating hormone, PTH: } \\
\text { Parathormone, CTX: Carboxy-terminal telopeptide }\end{array}$ \\
\hline
\end{tabular}



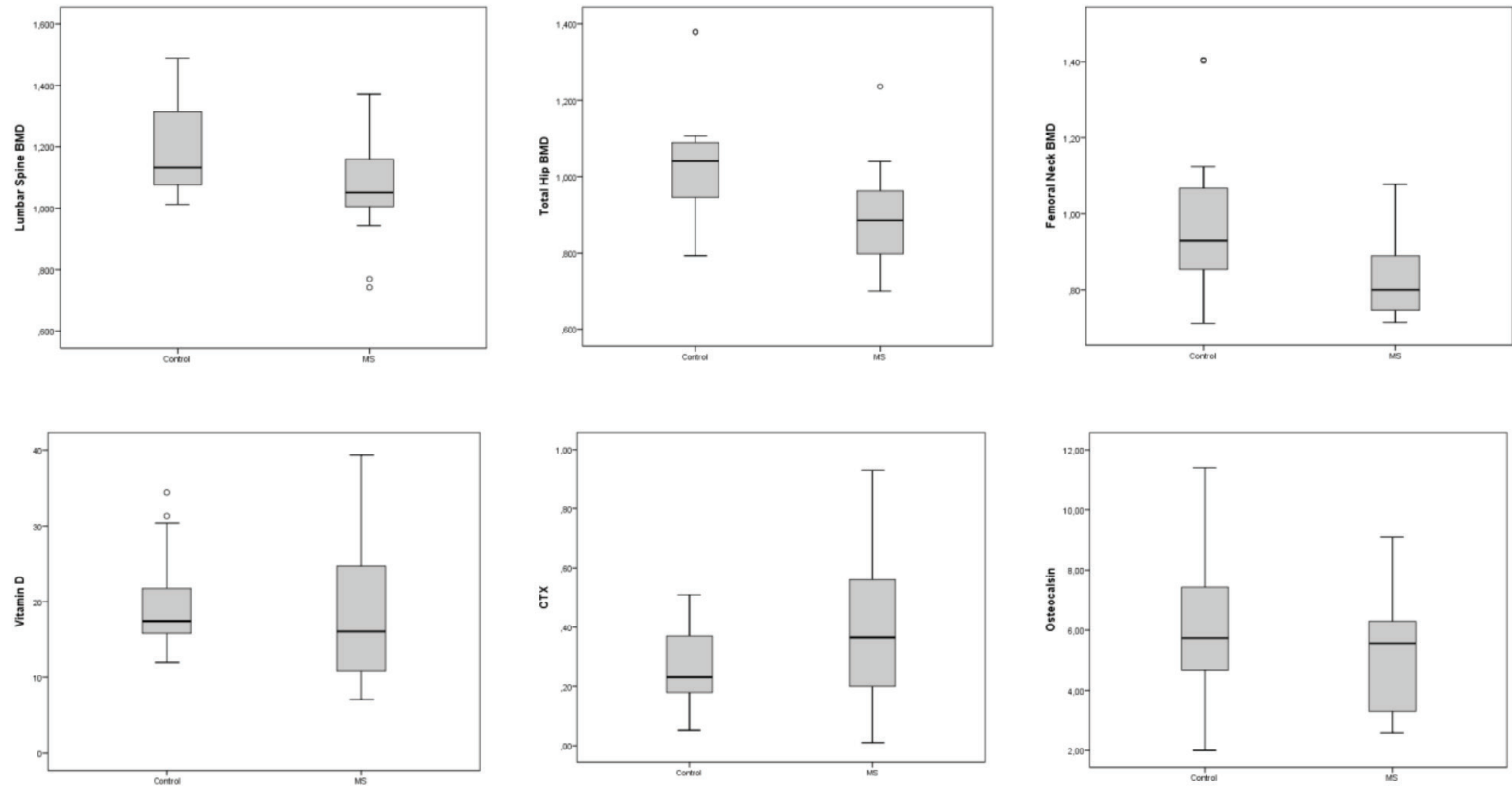

Figure 1. Comparison of the BMD, Vitamin D, OC and CTX of PPMS patients and control group BMD: Bone mineral density, OC: Osteocalcin, CTX: Carboxyterminal telopeptide of collagen I, PPMS: Primary progressive multiple sclerosis

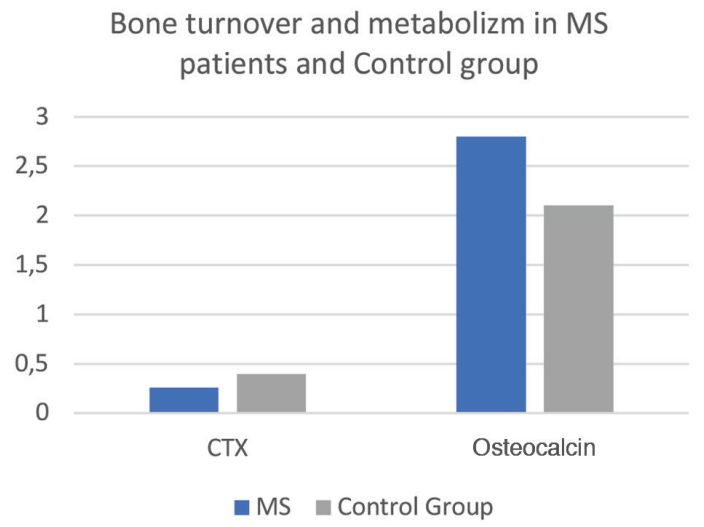

Figure 2. Comparison of the CTX and OC levels of the PPMS patients and control group

CTX: Carboxyterminal telopeptide of collagen I, OC: Osteocalcin, PPMS: Primary progressive multiple sclerosis

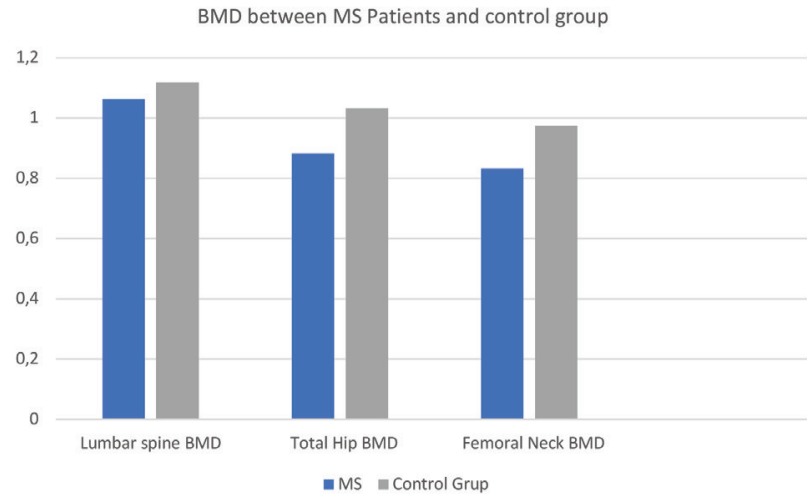

Figure 3. Comparison of the BMD results between PPMS patients and control group

BMD: Bone mineral density, PPMS: Primary progressive multiple sclerosis

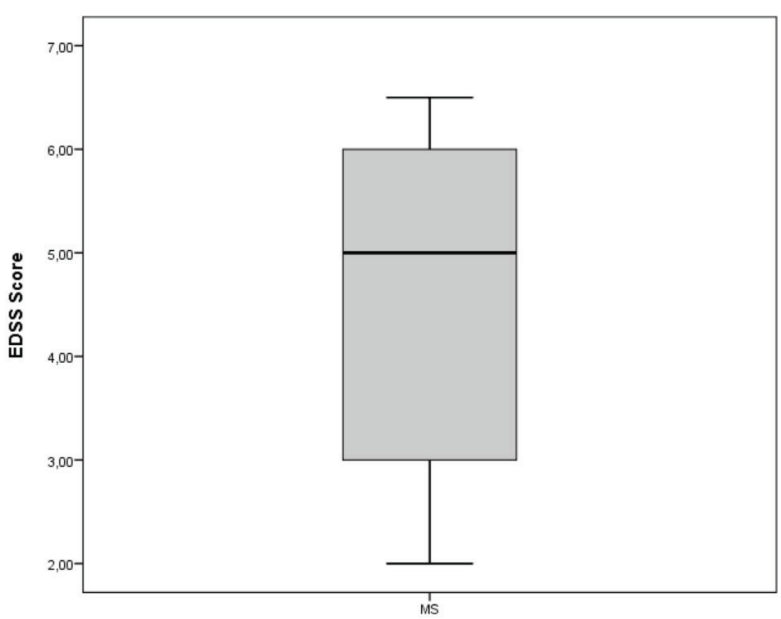

Figure 4. EDSS score distribution of PPMS patients EDSS: Expanded disability status scale, PPMS: Primary progressive multiple sclerosis

bone mineral deficiency by many factors, such as immobilization, steroid use, and cytokines $(13,14)$. Thus, patients with MS have faster bone loss and suffer fractures more often than healthy adults in their age group. In the NARCOMS study, Nickersonan et al. (15) reported that $27.2 \%$ of all MS patients have osteopenia and $15.4 \%$ have OP.

In a study comparing male and female bone loss, $80 \%$ of the male MS patients $(n=40)$ had bone loss in some level and $37.5 \%$ had OP. Whereas among the females $(n=47)$ osteoporotic patient ratio was $16.3 \%$ and and $7.4 \%$ of the pre-menopausal women ( $n=27)$ had OP (16).

Progressive immobilization in MS causes BMD loss, OP, and 
fractures. After 20-30 weeks of bed rest, healthy young adults have negative calcium balances of 150-200 mg daily. This loss is more prominent among paraplegic patients. The loss and disappearance of the biomechanical stress over the skeleton is the main cause of OP (17). Mechanical load increases bone formation in cortical and trabecular bone by decreasing bone turnover (18). In MS, there may be a decrease in BMD according to the level of ambulation, and decreased functional capacity can cause femoral BMD loss. Zikan et al. (19) indicated that femur trochanteric BMD was lower among wheelchair bound patients compared to ambulatory patients. Previously another study had also pointed out that the decrease in femoral BMD is correlated with poor ambulation (20). There are several other studies showing a positive correlation between physical activity and $\operatorname{BMD}(21,22)$.

Among non-ambulatory MS patients, the decrease of the axial mechanical load over the femur causes BMD loss. BMD loss due to an inadequate ambulation is more dominant in the femoral region than in the lumbar region (23). That is an important contributing factor in MS patients and we excluded this factor with including relatively mobile patients due to the EDSS score. Nevertheless we identified that the total BMDs of the lumbar and femur in the MS group were significantly lower than in the healthy controls. Whereas, there was no significant relationship between EDSS score and BMD. This may be explained by the fact that all patients were ambulatory, either assisted or independent, and the maximum EDSS score was 6.5 .

Continuous or intermittent steroid use is an another factor affecting BMD in MS patients. Steroid use has reportedly caused bone mass loss, and long-term steroid use causes OP by decreasing bone formation and increasing resorption $(24,25)$. Bone loss is observed among $30-50 \%$ of patients undergoing glucocorticoid treatment. Steroids affect bone metabolism through three mechanisms, calcium homeostasis, sex hormones, and inhibition of bone formation. They mainly inhibit bone formation directly by influencing osteoblast genes or growth factors. Eventually matrix formation is reduced (26). Some studies have shown loss of cortical bone volume and density after systemic steroid use (27).

Patients enrolled in our study had not used intravenous or oral steroid treatments within the last year, and in that way this important etyological factor was eliminated. Also we found no correlation between cumulative steroid use and BMD, but results among MS patients are controversial. Schwid et al. (28) showed that a 6-month pulse steroid treatment resulted in a significant increase in lumbar BMD but not in femoral BMD.

Vitamin D deficiency is another theory for explaining MS related $\mathrm{OP}$, and has an immunomodulatory effect and its deficiency decreases BMD. Kirbas et al. (29) showed that vitamin D levels and BMD of newly diagnosed MS patients were correlated. In both groups of our study vitamin $\mathrm{D}$ levels were in normal ranges. Remodeling of bone is an important determinant of bone strength. BTM are commonly used for the detection of bone turover. We measured serum CTX as a resorption marker and OC as a formation marker (6).

BMD measurements reflect a static condition of bone tissue. On the other hand, bone markers reveal the dynamic state. Studies showed no correlation between bone turnover markers and lower BMD measurements in early MS patients. We also did not find a relationship between either formation or resorption markers and BMD. These results are compatible with other studies in the literature $(6,30)$. However, there is limited data about bone formation markers. In conditions like MS, bone loss rate is not very prominent. Evidence regarding the bone formation markers are not sufficient yet, and therefore, bone formation markers cannot be used for diagnostic purposes (31).

Our study supports the view of MS-related OP independent of other risk factors, when excluded chronic immobilization and oral glucocorticoid use. This concept can be explained with the common etiological and pathological mechanisms of MS and OP. We would like to underlie the importance of considering bone health in male patients with PPMS. In addition to disease modifying therapies, lifestyle strategies focused on overall health and well-being should be emphasized as part of a management plan in MS patients.

\section{Ethics}

Ethics Committee Approval: This study was approved by the Hacettepe University Non-interventional Clinical Research Ethics Committee (decision no: GO 14/524-06) and carried out in accordance with the Declaration of Helsinki.

Informed Consent: Written informed consent was obtained from all participants.

Peer-review: Internally peer-reviewed.

\section{Authorship Contributions}

Surgical and Medical Practices: A.Ç.A., N.P.A., Concept: A.Ç.A., Y.G.K., Design: A.Ç.A., Y.G.K., Data Collection or Processing: A.Ç.A., N.P.A., F.A., S.K., R.K., Analysis or Interpretation: S.K., A.Ç.A., F.A., Literature Search: A.Ç.A., Y.G.K. Writing: A.Ç.A., Y.G.K., N.P.A., R.K.

Conflict of Interest: No conflict of interest was declared by the authors.

Financial Disclosure: This research was supported by the Scientific Research Unit of Hacettepe University.

\section{References}

1. Tarantino U, Iolascon G, Cianferotti L, Masi L, Marcucci G, Giusti $F$, et al. Clinical guidelines for the prevention and treatment of osteoporosis: summary statements and recommendations from the Italian Society for Orthopaedics and Traumatology. J Orthop Traumatol 2017;18(Suppl 1):S3-S36.

2. Khosla S, Amin S, Orwoll E. Osteoporosis in men. Endocr Rev 2008; 29:441-64.

3. Painter SE, Kleerekoper M, Camacho PM. Secondary osteoporosis: a review of the recent evidence. Endocr Pract $2006 ; 12: 436-45$.

4. Steffensen LH, Mellgren SI, Kampman MT. Predictors and 
prevalence of low bone mineral density in full ambulatory persons with multiple sclerosis. J Neurol 2010;257:410-8.

5. Drake MT, Murad MH, Mauck KF, Lane MA, Undavalli C, Elraiyah $\mathrm{T}$, et al. Clinical review. Risk factors for low bone mass-related fractures in men: a systematic review and meta-analysis. J Clin Endocrinol Metab 2012;97:1861-70.

6. Delmas PD, Eastell R, Garnero P, Seibel MJ, Stepan J. Committee of Scientific Advisors of the International Osteoporosis Foundation. The use of biochemical markers of bone turnover in osteoporosis. Osteoporos Int 2000;11 Suppl 6:S2-17.

7. Polman $\mathrm{CH}$, Reingold SC, Banwell B, Clanet M, Cohen JA, Filippi M, et al. Diagnostic criteria for multiple sclerosis: 2010 revisions to the McDonald criteria. Ann Neurol 2011:69:292-302.

8. Kurtzke J F. On the Origin of EDSS. Mult Scler Relat Disord 2015:4:95-103.

9. Assessment of fracture risk and its application to screening for postmenopausal osteoporosis. Report of a WHO Study Group. World Health Organ Tech Rep Ser 1994;843:1-129.

10. Writing Group for the ISCD Position Development Conference. Diagnosis of Osteoporosis in Men, Premenopausal Women, and Children. J Clin Densitom 2004;7:17-26.

11. Zikan V. Bone Health in Patients with Multiple Sclerosis. J Osteoporos 2011;2011:596294.

12. Laet $C D$, Kanis JA, Oden $A$, Johanson $H$, Johnell $O$, Delmas $P$, et al. Body mass index as a predictor of fracture risk: a meta-analysis. Osteoporos Int 2005;16:1330-8.

13. Formica CA, Cosman F, Nieveas J, Herbert J, Lindsay R. Reduced bone mass and fat-free mass in women with multiple sclerosis: effects of ambulatory status and glucocorticoid use. Caicif Tissue Int 1997;61:129-33.

14. Tüzün S, Altintas $A$, Karacan I, Tangürek S, Saip S, Siva A. Bone status in multiple sclerosis: beyond corticosteroids. Mult Scler 2003:9:600-4.

15. Nickersonan M, Cofieldb SS, Tyryc T, Salterb AR, Cutterb GR, Marrie RA. Impact of multiple sclerosis relapse: The NARCOMS participant perspective. Mult Scler Relat Disord 2015;4:234-40.

16. Weinstock-Guttman B, Gallagher E, Baier M, Green L, Feichter J, Patrick $\mathrm{K}$, et al. Risk of bone loss in men with multiple sclerosis. Mult Scler 2004;10:170-5.

17. Hearn AP, Silber E. Osteoporosis in multiple sclerosis. Mult. Scle 2010;16:1031-43.

18. Forwood MR. Mechanical effects on the skeleton: Are there clinical implications? Osteoporosis Int 2001;12:77-83.

19. Zikan V, Týblová M, Raška I Jr, Havrdová E, Luchavová M, Michalská
$D$, et al. Bone mineral density and body composition in men with multiple sclerosis chronically treated with low-dose glucocorticoids. Physiol Res 2012;61:405-17.

20. Schwid SR, Goodman AD, Puzas JE, McDermott MP, Mattson $\mathrm{DH}$. Sporadic corticosteroid pulses and osteoporosis in multiple sclerosis. Arch Neurol 1996;53:753-7.

21. Nordström P, Petterson U, Lorentzon R. Correlation of bone density to strength and physical activity in young men with a low or moderate level of physical activity. Calcif Tissue Int 1997;60:332-7.

22. Düppe $H$, Gardsell $P$, Johnell $O$, Nilsson BE, Ringberg K. Bone mineral density, muscle strength and physical activity. A populationbased study of 332 subjects aged 15-42 years. Acta Orthop Scand 1997:68:97-103.

23. Gibson JC, Summers GD. Bone health in multiple sclerosis. Osteoporos Int 2011:22:2935-49.

24. Olsson A, Oturai DB, Sorensen PS, Oturai PS, Oturai AB. Shortterm, high-dose glucocorticoid treatment does not contribute to reduced bone mineral density in patients with multiple sclerosis. Mult Scler 2015;21:1557-65.

25. Gupta S, Ahsan I, Mahfooz N, Abdelhamid N, Ramanathan M, Weinstock-Guttman B. Osteoporosis and multiple sclerosis: risk factors, pathophysiology, and therapeutic interventions. CNS Drugs 2014;28:731-42.

26. Azin A, Mohammad T, Shahriar N. Factors affecting bone mineral density in multiple sclerosis patients. Ir J Neurol 2013;12:19-22.

27. Ciccone A, Beretta S, Brusaferri F, Galea I, Protti A, Spreafico C. Corticosteroids for the long-term treatment in multiple sclerosis. Cochrane Database Syst Rev 2008;23:1-7.

28. Schwid SR, Goodman AD, Puzas JE, McDermott MP, Mattson $\mathrm{DH}$. Sporadic corticosteroid pulses and osteoporosis in multiple sclerosis. Arch Neurol 1996;53:753-7.

29. Kirbas A, Kirbas S, Anlar O, Turkyilmaz AK, Cure MC, Efe H. Investigation of the relationship between vitamin $\mathrm{D}$ and bone mineral density in newly diagnosed multiple sclerosis. Acta Neurol Belg 2013;113:43-7.

30. Stepan JJ, Havrdová E, Týblová M, Horáková D, Tichá V, Nováková I, et al. Markers of bone remodeling predict rate of bone loss in multiple sclerosis patients treated with low-dose glucocorticoids. Clin Chim Acta 2004;348:147-54.

31. Naylor KE, Jacques RM, Paggiosi M, Gossiel F, Peel NFA, McCloskey $\mathrm{EV}$, et al. Response of bone turnover markers to three oral bisphosphonate therapies in postmenopausal osteoporosis: the TRIO study. Osteoporos Int 2016;27:21-31. 